\title{
RECENT DEVELOPMENTS IN INDIANA F AMILY LAW: OCTOBER 2014 TO SEPTEMBER 2015
}

\author{
MARGARET RYZNAR ${ }^{*}$
}

This Article considers the notable developments in Indiana family law during the survey period of October 1, 2014 to September 30,2015. The Indiana statutes and published appellate cases surveyed in this Article concern same-sex marriage, property division upon divorce, grandparent visitation and parenting time, child custody and child support, CHINS and the termination of parental rights, adoption, and jurisdiction and procedure.

\section{SAME-SEX MARRIAGE}

Among the most significant family law changes during the survey period occurred on a national scale when the U.S. Supreme Court decided Obergefell $v$. Hodges, ${ }^{1}$ in which the Court established a constitutional right to same-sex marriage. A year before Obergefell, the U.S. Court of Appeals for the Seventh Circuit had declared unconstitutional Indiana's statutory ban on same-sex marriage. ${ }^{2}$ Although the U.S. Supreme Court did not grant certiorari in that Seventh Circuit case, the Court granted certiorari in Obergefell, a subsequent case from the U.S. Court of Appeals for the Sixth Circuit dealing with a similar samesex marriage ban. ${ }^{3}$

In Obergefell, the U.S. Supreme Court discussed the constitutional protection for same-sex marriage found in the Fourteenth Amendment of the U.S. Constitution. ${ }^{4}$ The Court had previously interpreted this Amendment to encompass various constitutional rights not explicitly enumerated, including, for example, parental rights, the right to marital privacy involving the use of contraceptives, and the right to marry. ${ }^{5}$ In Obergefell, the Court confirmed the right to marry applied to same-sex couples for the same reasons it applied to opposite-sex couples, such as the benefits of supporting marriage in society. ${ }^{6}$

\section{PROPERTY DIVISION}

During the survey period, Indiana courts decided a few cases related to the property division between spouses upon divorce. ${ }^{7}$ This included a case examining the validity of a premarital agreement ${ }^{8}$ that a woman had signed when she was

* Associate Professor of Law, Indiana University Robert H. McKinney School of Law.

1. 135 S. Ct. 2584 (2015).

2. Baskin v. Bogan, 766 F.3d 648 (7th Cir.), cert. denied, 135 S. Ct. 316 (2014).

3. Obergefell, $135 \mathrm{~S}$. Ct. at 2588.

4. Id. at 2597.

5. Id. at 2616 .

6. Id. at 2601 .

7. See, e.g., Crider v. Crider, 26 N.E.3d 1045 (Ind. Ct. App. 2015).

8. Fetters v. Fetters, 26 N.E.3d 1016 (Ind. Ct. App.), trans. denied, 34 N.E.3d 1233 (Ind. 2015).

http://dx.doi.org/10.18060/4806.01121 
just sixteen years old and about to marry a man fifteen years her senior. ${ }^{9}$ At the time, they were expecting their first child together. ${ }^{10}$ They subsequently had a second child, and she cared for both children while working low-wage jobs, never having completed a GED. ${ }^{11}$ At the time of her divorce, she worked as a nurse's aide, earning under $\$ 10$ per hour and working fifteen to thirty-five hours per week, with no retirement plan. ${ }^{12}$ She owned no real property, but owned two cars in her name worth a total of $\$ 13,900 .{ }^{13}$ During the marriage, her husband worked as a janitor, earning approximately $\$ 590$ per week and accumulating a pension worth approximately $\$ 38,000 .{ }^{14}$ They lived in a home he had acquired before the marriage, worth $\$ 62,000 .{ }^{15}$ The husband owned two cars and one motorcycle in his own name, worth a total of $\$ 8,500 .^{16}$

Under the premarital agreement, the parties would retain their own separate property in the case of a divorce. ${ }^{17}$ Despite not being able to read very well and not understanding the agreement, the woman and her mother had signed it in the groom's attorney's office. ${ }^{18}$

When the couple sought to divorce, the trial court enforced the premarital agreement, but the Indiana Court of Appeals held the agreement to be invalid ${ }^{19}$ and unconscionable as a matter of law given the "gross disparity in life experience" between the parties at the time it was signed.$^{20}$ Furthermore, the court noted that contracts entered into by minors are voidable at the option of the minors while they remain minors, or within a reasonable time after they reach the age of majority. ${ }^{21}$ Finally, the Indiana Court of Appeals held the woman could challenge the agreement and was not prevented by laches or estoppel from doing so. ${ }^{22}$

In another case related to property division, a former husband sought to set aside a dissolution decree issued several years earlier on account of fraud by the former wife in failing to disclose assets that should have been divisible. ${ }^{23}$ The lower court dismissed the former husband's motion as untimely filed, which the appellate court affirmed after examining the approaches of other jurisdictions. ${ }^{24}$
9. Id. at 1019 .
10. $I d$.
11. Id.
12. Id.
13. Id.
14. Id.
15. Id.
16. Id.
17. Id.
18. Id.
19. Id. at 1023 .
20. Id. at 1021 .
21. Id. at 1023 .
22. Id.
23. Jahangirizadeh v. Pazouki, 27 N.E.3d 1178, 1180 (Ind. Ct. App. 2015).
24. Id. at 1185 . 
The Indiana Court of Appeals ultimately determined the alleged fraud was "ordinary" fraud that neither gave rise to an independent action for fraud to set aside a judgment nor amounted to fraud on the court, which would be exempt from the one-year period for seeking relief from judgment. ${ }^{25}$

\section{GRANDPARENT VISITATION}

Grandparent visitation made several appearances in the case law during the survey period. In one such case, a child's maternal grandparents filed for visitation under the Grandparent Visitation Act after their relationship with the child's father became contentious. ${ }^{26}$ Their daughter had recently died of cancer and expressed her wishes in her will for them to have generous visitation with her child. ${ }^{27}$ Based on the opinion of mental health experts, the trial court determined it was in the child's best interest to have a relationship with the grandparents totaling approximately seventy-nine days per year. ${ }^{28}$ The court of appeals found this visitation amount improper under the Grandparent Visitation Act, but the court noted the lack of guidance regarding the proper amount. ${ }^{29}$ After reviewing the circumstances of this particular case-including the closeness of the child to the maternal grandparents due to the father's demanding work schedule- the Indiana Supreme Court affirmed the trial court's order of visitation. ${ }^{30}$

In another case, after a previous restriction of their visitation rights on remand, grandparents petitioned to resume visitation and requested a visitation evaluation. ${ }^{31}$ The Indiana Court of Appeals determined the paternal grandparents lacked standing to request a visitation evaluation and the trial court lacked authority to order a custody evaluation sua sponte. ${ }^{32}$

In yet another grandparent visitation case during the survey period, the Indiana Court of Appeals held that a grandmother had no standing to seek visitation under the grandparent visitation statute after the stepparent had already adopted the child. ${ }^{33}$ The court held that a grandparent's visitation rights must be established at the time of the stepparent adoption to qualify as "visitation rights" under the grandparent visitation statute. ${ }^{34}$

A final grandparent visitation case involved a paternal grandmother who petitioned for visitation rights following the death of the child's father. ${ }^{35}$ The

25. Id. at 1184 .

26. In re Visitation of L-A.D.W., 38 N.E.3d 993 (Ind. 2015).

27. Id. at 994.

28. Id.

29. Id.

30. Id. at 1001 .

31. In re Guardianship of C.R., 22 N.E.3d 657, 659 (Ind. Ct. App. 2014).

32. Id. at 662 .

33. Jocham v. Sutliff, 26 N.E.3d 82, 87 (Ind. Ct. App.), trans. denied, 31 N.E.3d 976 (Ind. 2015).

34. $I d$.

35. In re Grandparent Visitation of K.M., 42 N.E.3d 572, 575 (Ind. Ct. App. 2015). 
grandmother had regularly visited the child during the first seven months, but stopped communicating while there was a protective order against the father because she feared it would seem like indirect contact on the father's part. ${ }^{36}$ The appellate court affirmed it was in the child's best interests to have a relationship with the grandmother, ${ }^{37}$ but noted that following the Indiana Parenting Time Guidelines for grandparent visitation was excessive and the trial court should determine visitation based on the mother and child's impending move across the country to follow mother's fiancé in his military assignment. ${ }^{38}$

\section{PARENTING Time}

During the survey period, the Indiana Court of Appeals heard various cases related to parenting time. ${ }^{39}$ In one dispute regarding parenting time restrictions, the court allowed a father to reveal his paternity to his child because there is no evidence it would cause any mental or physical harm to the child. ${ }^{40}$ In another case, the Indiana Court of Appeals held the trial court did not abuse its discretion in denying a mother's request for a parenting time coordinator despite evidence the parents did not get along. ${ }^{41}$

In yet another case during the survey period, a mother's visitation was ended after she "behaved inappropriately during visits, inserted herself in between her child and the foster parent in inappropriate ways, refused to participate in services aiming to help her become a better parent, and denied doing anything inappropriate as a parent." ${ }^{, 42}$ Although there is no Indiana statute specifically addressing parenting time in the CHINS context, the court was guided by Indiana Code section 31-17-4-2, which instructs that parenting rights should not be restricted unless the parent endangers the child's physical health or significantly impairs the child's emotional development. ${ }^{43}$

In a separate case, the trial court awarded the husband sole legal and physical custody of the couple's biological minor child, and granted him visitation with his stepchild. ${ }^{44}$ The court found the wife in contempt when she willfully interfered with visitation. ${ }^{45}$ The Indiana Court of Appeals affirmed, determining the trial court had the authority to grant visitation to the husband when it was in the best interests of the stepchild, to enter a custody arrangement not requested by either party, and to conclude the wife willfully interfered with the visitation order by

36. Id. at 574 .

37. Id. at 580 (internal quotations omitted).

38. Id. at 581-82.

39. See, e.g., Patton v. Patton, 48 N.E.3d 17 (Ind. Ct. App. 2015).

40. In re Paternity of Snyder, 26 N.E.3d 996, 999 (Ind. Ct. App. 2015).

41. Clary-Ghosh v. Ghosh, 26 N.E.3d 986, 995 (Ind. Ct. App.), trans. denied, 31 N.E.3d 975 (Ind. 2015).

42. In re E.W., 26 N.E.3d 1006, 1010 (Ind. Ct. App. 2015).

43. Id. at 1009 .

44. Richardson v. Richardson, 34 N.E.3d 696, 699 (Ind. Ct. App. 2015).

45. Id. 
removing the children from his care and preventing him from seeing them. ${ }^{46}$

Finally, a father successfully "filed a motion seeking to have mother held in contempt of court due to her failure to allow [him] to exercise visitation time." ${ }^{\text {"47 }}$ The Indiana Court of Appeals determined the trial court did not violate the mother's due process rights by excluding evidence regarding the reason for the father's delay in providing the child's exact pick up and drop off times. ${ }^{48}$ The court also concluded there was sufficient evidence to support the finding that the mother willfully violated the terms of their divorce decree. ${ }^{49}$

\section{ChILd Custody}

Indiana law allows a change of child custody when (1) modification is in the best interests of the child; and (2) there is a substantial change in at least one of the factors the court may consider in initially determining custody. ${ }^{50}$ During the survey period, the Indiana Court of Appeals determined there had been a change meriting modification of child custody when mother re-married and established a permanent home, while father increased his work hours. ${ }^{51}$

In another case, a mother argued the trial court did not have subject matter jurisdiction and abused its discretion when it modified a child custody order. ${ }^{52}$ The Indiana Court of Appeals found that by agreeing on child custody and visitation as part of the paternity proceeding, mother stipulated to the jurisdiction of the trial court over child custody. ${ }^{53}$ The court found no error in the lower court's decision to modify the child custody award by switching custody to the father. ${ }^{54}$

\section{CHILD SUPPORT}

A divorced mother petitioned to modify the father's child support obligation to which they had agreed earlier, arguing that (1) the support order was issued more than twelve months prior and (2) there was more than a twenty percent $(20 \%)$ difference between the support he paid under their settlement agreement and an amount ordered pursuant to the Child Support Guidelines. ${ }^{55}$ Father countered that Indiana precedent required a "substantial and continuing change in circumstances" to make the original terms of the child support unreasonable

46. Id.

47. Akiwumi v. Akiwumi, 23 N.E.3d 734, 736 (Ind. 2014).

48. Id. at 740 .

49. Id. at 741 .

50. Steele-Giri v. Steele, 40 N.E.3d 513, 523 (Ind. Ct. App. 2015), vacated, 2016 WL 1033458 (Ind. 2016).

51. Id. at 524 .

52. In re Paternity of J.G., 19 N.E.3d 278, 279 (Ind. 2014).

53. Id. at 282 .

54. Id. at 283 .

55. Rolley v. Rolley, 22 N.E.3d 558, 558 (Ind. 2014). 
after the parties agreed to it. ${ }^{56}$

There was conflicting precedent on this issue, and the Indiana Supreme Court adopted Judge Pyle's analysis and the result reached by the Court of Appeals in the present appeal: Judge Pyle acknowledged that while a change in circumstances and the $20 \%$ difference were ordinarily independent grounds for a child support modification, Indiana "precedent has created an exception for circumstances where a support order is based on an agreement between the parties" and this exception required "changed circumstances so substantial and continuing as to make the terms unreasonable. ${ }^{.57}$ However, despite the absence of such changed circumstances, Judge Pyle nonetheless allowed the modification of the father's agreed-upon child support amount. Such modification was allowed under the plain language of the child support modification statute, as well as because of the paramount importance of the child's well-being and the fact that "the law governing child support agreements differ[ed] from that law governing other contractual agreements. ${ }^{958}$ The Indiana Court of Appeals concluded the trial court correctly granted the mother's petition to modify the father's child support obligations. ${ }^{59}$

On the matter of child support, the Indiana Supreme Court also determined " $a$ [f]ather waived his challenge to the form of the summary proceeding when he failed to make a contemporaneous objection to that procedure." ${ }^{.60}$ Nonetheless, "the trial court properly conducted a summary proceeding under the agreement of both parties, and the court was permitted to rely upon the arguments of counsel and limited informal documentary evidence when it entered its findings." ${ }^{" 61}$ The trial court did not err in deviating from the Indiana Child Support Guidelines by not granting the father a full parenting time credit for overnight visits and in permitting the mother to claim the federal and state dependency tax exemption for the child each year, instead of alternating it with the father. ${ }^{62}$

On the issue of postsecondary education awards, as a matter of first impression, the Indiana Court of Appeals decided the trial court could not, under Indiana Code section 31-16-6-6, order a parent to pay educational support for a child who was already nineteen, where the court issued the original child support order in August 2000 before issuing a more recent order after June 30, $2012 .^{63}$ The Indiana General Assembly had previously lowered the presumptive age for the termination of child support from twenty-one to nineteen, which became effective on July 1, 2012. ${ }^{64}$ Thus, according to the court, where the most

56. $I d$.

57. Rolley v. Rolley, 13 N.E.3d 521, 526 (Ind. Ct. App.), aff'd in part, vacated in part, 22 N.E.3d 558 (Ind. 2014).

58. Id.

59. Id.

60. Bogner v. Bogner, 29 N.E.3d 733, 746 (Ind. 2015).

61. Id.

62. $I d$.

63. Neal v. Austin, 20 N.E.3d 573, 574 (Ind. 2014).

64. Id. at 575 . 
recent order establishing a child support obligation was issued after June 30, 2012 , the child must file a petition for educational needs before turning nineteen years of age. ${ }^{65}$

In another case on postsecondary education during the survey period, the Indiana Court of Appeals held the trial court erred by basing a father's postsecondary award on the costs of a private university instead of a public university. ${ }^{66}$ The child gained admission to Indiana University, Ball State University, and DePauw University, with a financial aid package at each school. ${ }^{67}$ The child instead chose Butler because she thought it would provide a better education and she wanted to attend there.$^{68}$ However, the court noted there was "no evidence that Butler offered a special curriculum" despite its high costs or that the child discussed the decision with her father. ${ }^{69}$ Instead, the child simply told her father about her decision and "asked him to help pay for it." ${ }^{.70}$ The appellate court determined the trial court abused its discretion because this was against the logic and effect of the circumstances before it. ${ }^{71}$ A previous Indiana case held that "[i]n determining whether educational support should be limited to the cost of in-state, state-supported colleges, the trial court should balance 'the advantages of the more expensive college in relation to the needs and abilities of the child with the increased hardship of the parent." ${ }^{, 72}$

\section{CHINS AND the TERmination of PARENTAl Rights}

The Indiana Court of Appeals determined during the survey period, as a matter of first impression, that the Department of Child Services' (DCS) alleged failure to provide services to a parent, such as parenting aid and supervised visitation, did not toll the statutory waiting period before the hearing to terminate parental rights. $^{73}$ The court held that "Indiana Code Section 31-35-24(b)(2)(A)(iii) simply requires the DCS to demonstrate compliance with the statutory waiting period - namely, that a child has been removed from a parent for fifteen of the most recent twenty-two months immediately prior to the termination hearing." waiting period on whether the DCS provided any type of services to the parent."

In another case, a father's parental rights were terminated after the Indiana

65. Id. at 578 .

66. In re Paternity of Pickett, 44 N.E.3d 756, 771 (Ind. Ct. App. 2015).

67. Id. at 768 .

68. Id.

69. Id.

70. Id.

71. Id.

72. Id. at 767-68 (citing Hinesley-Petry v. Petry, 894 N.E.2d 277, 281 (Ind. Ct. App. 2008)).

73. In re J.W., 27 N.E.3d 1185, 1190 (Ind. Ct. App.), trans. denied, 34 N.E.3d 251 (Ind. 2015).

74. Id. at 1186.

75. Id. 
Department of Child Services filed a petition for the involuntary termination of his rights. ${ }^{76} \mathrm{He}$ appealed but lost in the Indiana Court of Appeals, which found harmless "any error in admitting the [Allen County Department of Child Services] supervisor's hearsay testimony" regarding the father's lack of improvement in parenting because other evidence supported the court's finding that the father would not remedy the conditions that resulted in his child's removal. ${ }^{77}$

The Indiana Court of Appeals also determined in a different case that due process requires the completion of a fact-finding hearing when a father challenged the allegations in the CHINS petition. ${ }^{78}$ This includes the "presentation of evidence and argument by both parents, if present in person or by counsel, before [a child] is adjudicated a CHINS."79

During the survey period, the Indiana Supreme Court also reversed a CHINS adjudication, determining the trial court's derogatory comments and pressure to waive a fact-finding hearing violated the father's due process rights. ${ }^{80}$ The trial court had labelled the parties' dispute "ridiculous and retarded," blamed the parties for "stupidity," and continued the hearing to a new date to order the parties into mediation. ${ }^{81}$

In another case, the Indiana Supreme Court found insufficient evidence that a father could not remedy the conditions for his child's removal and that he posed a threat to the child's well-being. ${ }^{82}$ Although the father had been in prison, he extensively tried to better himself "by learning parenting skills, addressing his problems with substance abuse, and establishing a bond with his children." ${ }^{" 83}$ This case was distinguished by a later Indiana Court of Appeals case, ${ }^{84}$ where the father's parental rights were terminated after he stabbed the children's uncle in front of them and received a prison sentence with a release date of almost five years after the proposed termination of his rights. ${ }^{85}$

Finally, in another case, the court of appeals affirmed a denial of a mother's "petition to expunge a substantiated report of child neglect regarding her children. ${ }^{\circ 86}$ The court determined the mother's burden of proof was clear and convincing evidence, which is greater than a preponderance of the evidence. ${ }^{87}$ "It was not unreasonable for the juvenile court to deny her petition where the only

76. D.B.M. v. Ind. Dep't of Child Servs., 20 N.E.3d 174, 177 (Ind. Ct. App. 2014), trans. denied, 24 N.E.3d 967 (Ind. 2015).

77. Id. at 180 .

78. In re L.C., 23 N.E.3d 37, 42 (Ind. Ct. App.), trans. denied, 29 N.E.3d 123 (Ind. 2015).

79. $I d$.

80. In re J.K., 30 N.E.3d 695, 696 (Ind. 2015).

81. Id. at 697.

82. K.E. v. Ind. Dep't of Child Servs., 39 N.E.3d 641, 646 (Ind. 2015).

83. Id. at $643-44$.

84. In re B.H., 44 N.E.3d 745 (Ind. Ct. App. 2015), trans. denied, 43 N.E.3d 244 (Ind. 2016).

85. Id. at 747,751 .

86. G.E. v. Ind. Dep’t of Child Servs., 29 N.E.3d 769, 769 (Ind. Ct. App. 2015).

87. Id. at 771-72 (citing In re G.Y., 904 N.E.2d 1257, 1260 n.1 (Ind. 2009)). 
evidence presented was her testimony" that she had not used any controlled substances since 2003, was in contact with all of her children and some grandchildren, and had not committed any crimes or had any more contact with the juvenile courts. ${ }^{88}$

\section{ADOPTION}

A new statutory provision will help offset adoption expenses for Indiana residents. Since January 1, 2015, Indiana taxpayers may claim a state tax credit for adopting a child. ${ }^{89}$

In addition to this new provision, there have been several Indiana cases examining different aspects of the Indiana adoption statutory framework.$^{90}$ For example, Indiana law requires the adoption consent of those having lawful custody of a child, but does not define who has lawful custody. ${ }^{91}$ The Indiana Supreme Court determined the term to include those who meet the statutory definition of a de facto custodian at the time of the petition for adoption. ${ }^{92}$ Therefore, maternal grandparents who had de facto custody of the child must receive notice of and an opportunity to consent to a stepfather's adoption proceedings. ${ }^{93}$

The Indiana Supreme Court also upheld the constitutionality of an Indiana statute that prohibited people with certain felony convictions from adopting a child, as applied to a child's maternal grandmother and her fiancé, because the prohibition was "rationally related to a legitimate legislative purpose and did not discriminate against a suspect class." ${ }^{.94}$ Further, even if the adoption were in the children's best interests, the fiancé had been convicted of armed robbery in Iowa and of burglary twice in Illinois, while the grandmother had previously pleaded guilty to the neglect of a dependent, a Class D felony. ${ }^{95}$

Finally, the Indiana Supreme Court considered the duties related to the Indiana putative father registry. ${ }^{96}$ In the case, prospective adoptive parents, facilitated by Catholic Charities, took custody of a child on May 3, 2010 after the biological mother consented to the adoption. ${ }^{97}$ On May 25 and again on June 1, Catholic Charities requested the Indiana Department of Health to check whether

88. Id. at 772 .

89. IND. CODE $\S 6-3-3-13$ (2015).

90. E.g., In re Adoption I.B., 32 N.E.3d 1164 (Ind. 2015); In re Adoption of B.C.H., 22 N.E.3d 580 (Ind. 2014).

91. In re Adoption of B.C.H., 22 N.E.3d at 580.

92. Id.

93. Id. at 587-88.

94. In re Adoption I.B., 32 N.E.3d at 1170-72.

95. Id. at 1167-68.

96. Kramer v. Catholic Charities of the Diocese of Fort Wayne-South Bend, Inc., 32 N.E.3d 227 (Ind. 2015).

97. Id. at 229-30. 
a man had registered as the putative father of the child.$^{98}$ Although the first search showed no registered putative fathers, the second search inexplicably revealed that a man had registered as the putative father..$^{99}$ Despite learning of the putative father, the prospective adoptive couple petitioned to adopt the child, which the putative father contested. ${ }^{100}$ Upon proving his paternity, the putative father gained custody of the child in early January 2011, after the adoptive couple had custody of the child for over eight months. ${ }^{101}$

Distraught, the prospective adoptive parents sued Catholic Charities for negligence, alleging that the organization should have checked the putative father registry before placing the child with them, and should have notified them of its failure to do so. Catholic Charities moved for summary judgment, arguing the couple had executed certain releases that barred a negligence claim and that the organization had satisfied any duty owed to the couple by complying with the putative father registry statute. ${ }^{102}$

The trial court granted summary judgment for Catholic Charities. ${ }^{103}$ However, the court of appeals reversed, finding that the releases signed by the couple did not specifically waive a negligence claim and thus did not bar the couple's negligence case. ${ }^{104}$ The supreme court affirmed the trial court, however, noting the prospective adoptive couple did not demonstrate that Catholic Charities had any obligations with respect to the putative father registry beyond the statutory ones. ${ }^{105}$

\section{JURISDICTION \& PROCEDURE}

On a jurisdictional point, the Indiana Supreme Court held during the survey period a "statutory provision that set forth the exclusive jurisdiction in all adoption matters to probate courts in any county that had a separate probate court did not confer exclusive adoption jurisdiction on the superior court's civil division." ${ }^{106}$ Transfer of an adoption matter to the juvenile court was thus granted. ${ }^{107}$

In another case, during proceedings addressing a mother's child support modification petition for post-secondary education expenses, the mother sought to join Ball State University as a defendant so that the University would release her daughter's transcript. ${ }^{108}$ The daughter could not enroll at Indiana University

98. Id. at 230 .

99. Id.

100. $I d$.

101. $I d$.

102. $I d$.

103. Id.

104. Id.

105. Id. at 229.

106. In re Adoption of J.T.D., 21 N.E.3d 824, 824 (Ind. 2014).

107. Id. at 832 .

108. Ball State Univ. v. Irons, 27 N.E.3d 717, 719 (Ind. 2015). 
Northwest without it, but Ball State withheld it because she owed tuition money. ${ }^{109}$ The lower court joined Ball State as a defendant and ordered it to release the transcript. ${ }^{110}$ The Indiana Supreme Court determined Ball State could appeal the non-final order compelling it to release the transcript and further held joining Ball State was not necessary in the case. ${ }^{111}$

The Indiana Court of Appeals also held during the survey period that because a father "failed to object at any time to [the same judge] presiding over both his [parental rights] termination and criminal matters, he waived any claim of error in that context." "12 The court additionally concluded there was sufficient evidence for the trial court to terminate the father's parental rights. ${ }^{113}$

In another case, a wife filed a motion to transfer venue after the husband filed for divorce. ${ }^{114}$ The Indiana Court of Appeals determined the preferred venue was the county in which the divorce was filed. ${ }^{115}$ The court reasoned that "a dissolution action is a proceeding created and recognized by statute," and the plain language of Indiana Trial Rule 75(A)(8) states the preferred venue lies in "the county where a claim in the plaintiff's complaint may be commenced under any statute recognizing or creating a special or general remedy or proceeding."116

In yet another case on jurisdiction, a father appealed a court's denial of his motion to vacate a guardianship order that awarded custody of his child to a guardian because he later registered the paternity order with another court. ${ }^{117} \mathrm{He}$ argued this gave the latter court exclusive jurisdiction over the paternity action, in which he attempted to include the prior guardianship action. ${ }^{118}$ Therefore, the father argued the original court "lacked jurisdiction to determine who would receive custody of [the child] at the time it issued its guardianship order." 119 The Indiana Court of Appeals determined the original court had "jurisdiction to enter its guardianship order and did not abuse its discretion in ordering restricted parenting time." ${ }^{120}$

Additionally during the survey period, the Indiana Court of Appeals held the trial court had jurisdiction over the custody of an unborn child following a divorce. ${ }^{121}$ The court also noted Indiana was the appropriate forum for the custody dispute as opposed to Canada, where the mother returned after the end of her

109. Id.

110. Id. at $719-20$.

111. Id. at 719 .

112. In re E.P., 20 N.E.3d 915, 917 (Ind. Ct. App. 2014), trans. denied, 25 N.E.3d 747 (Ind. 2015).

113. Id.

114. Strozewski v. Strozewski, 36 N.E.3d 497, 497 (Ind. 2015).

115. Id.

116. Id. at 500 .

117. In re B.J.N., 19 N.E.3d 765, 768 (Ind. Ct. App. 2014).

118. Id. at 767-68.

119. Id.

120. Id. at 766 .

121. Barwick v. Ceruti, 31 N.E.3d 1008, 1010 (Ind. Ct. App. 2015). 
marriage. ${ }^{122}$

The Indiana Court of Appeals also noted the precedent for a superior court to have the authority to use its contempt power to enforce a judgment for maintenance. ${ }^{123}$ The lower court thus incorrectly determined a support award was not enforceable by contempt. ${ }^{124}$

In another case, a minor obtained an abortion without her mother's consent, with the assistance of her boyfriend's mother. ${ }^{125}$ The patient's mother and the patient herself, upon reaching an age of majority, later brought an action against the abortion provider, Planned Parenthood. ${ }^{126}$ The Indiana Court of Appeals held the abortion statute does not establish a private cause of action. ${ }^{127}$ The court also noted Planned Parenthood believed in good faith the minor patient was authorized to consent as an eighteen-year-old because she was using a false identification card that stated she was of the minimum age to consent to the abortion. ${ }^{128}$

Finally, a mother petitioned a trial court for appellate attorney fees and received them pursuant to Indiana Code section 31-15-10-1 due to the differing economic circumstances of the parties. ${ }^{129}$ Father contended Indiana Appellate Rule 66 should be applied to determine if an award of attorney fees is warranted, even though the appellate attorney fees were requested in a trial court. ${ }^{130}$ The Indiana appellate court determined "the trial court was not required to consider Appellate Rule 66(E) in awarding [mother's] appellate attorney fees."

In sum, Indiana courts decided a wide variety of family law cases during the survey period of October 1, 2014 to September 30, 2015. Topics ranged from property division upon divorce to child custody, but legal issues remain and future cases will be of interest.

122. Id. at 1008 .

123. Whittaker v. Whittaker, 44 N.E.3d 716, 717 (Ind. Ct. App. 2015).

124. Id.

125. Lockett v. Planned Parenthood of Ind., Inc., 42 N.E.3d 119, 124 (Ind. Ct. App. 2015), trans. denied, 43 N.E.3d 1280 (Ind. 2016).

126. Id. at 125 .

127. Id. at 119 .

128. Id. at 134 .

129. Townsend v. Townsend, 20 N.E.3d 877, 883 (Ind. Ct. App. 2014), trans. denied, 29 N.E.3d 124 (Ind. 2015).

130. Id. at 879-80.

131. Id. at 883 . 